Print ISSN: 2052-6393(Print),

Online ISSN: 2052-6407(Online)

\title{
THE DETERMINANTS OF NETFLIX ADOPTION IN INDONESIA
}

\author{
Fernanda Fernandhytia \\ Business Management, Accounting, Bina Nusantara International Business School, \\ Jakarta \\ Bernadus Roy Bagaskara \\ Business Management, Information System, Bina Nusantara International Business \\ School, Jakarta \\ AdillaAnggraeni \\ Marketing, Management, Bina Nusantara International Business School, Jakarta
}

\begin{abstract}
The research studies the impact of social innovation, consumer innovativeness, perceived benefits, perceived ease of use, and perceived cost on the adoption of Netflix as a flexible subscription among its users in Indonesia. It classified as quantitative with a descriptive causal approach and uses an online survey as a data collection method with 265 total respondents within the age of 18 years old and older. The data is analyzed using the SPSS with tests of coefficients of determination, multiple linear regression, and the T-test. According to the findings, the coefficient of determination obtained is 0.512 which indicated that $51.2 \%$ of the consumer adoption of Netflix is affected by several factors. We also finds that service innovation, consumer innovativeness, perceived ease of use, perceived usefulness, and perceived cost have a direct significant impact on consumer adoption of Netflix in Indonesia, individually and mediated.
\end{abstract}

KEYWORDS: consumer adoption, netflix, technology acceptance model, consumer innovativeness, service innovation, perceived ease of use.

\section{INTRODUCTION}

Netflix began as a DVD rental service with no due dates in 2007, but has since expanded to include various platforms for the distribution of its movies and TV episodes. Soon after its debut, it added several other platforms as streaming media, including Xbox 360, TV set boxes, Blue-ray players, PS3, Nintendo Wii, Smart TVs, and all internetconnected devices. All of these actions were followed by their rapid expansion to expand internationally, which was warmly received by consumers (Hosch, 2020). Netflix's recent development in expanding its service to be accessible across all platforms has taken a toll on cable services, as people have grown more comfortable with the ability to use the service wherever and whenever they want, instead of having to adhere to a regular show schedule like cable services. Despite having to deal with a number of government issues during their debut in 2016, including the censorship of certain series that were considered inappropriate due to Indonesian norms, as well as governmental regulations including article 44/2008 on Pornography in Television

ECRTD-UK https://www.eajournals.org/

ULR: https://doi.org/10.37745/ijbmr.2013 
Print ISSN: 2052-6393(Print), Online ISSN: 2052-6407(Online)

Programs and article 27 (1)/2008 on Information and Electronic Transactions, they managed to succeed (Putri, 2020).

The growth in the percentage of Netflix users in Indonesia over the year has been attributed to an improvement in the quality of services provided by Netflix through the apps, responses, and product variants offered (Marchand \& Marx, 2020). Netflix has also been recognized for being extremely attentive to customer demands, always on the lookout for new features, new tv programs, and movie adaptations to add to its catalogue in response to customer demands. Aside from Netflix's usability and usefulness, their ability to adapt well to consumer price demand has consistently piqued consumer interest and increased market adoption of the brand. Netflix's competitors in Indonesia are primarily ones that provide similar services, such as iFlix or GoPlay, as well as local cable television service providers including first Media, which charges Rp. 315,000.00 per month, or MNC Indovision, which charges Rp. 453,000.00 per month for the first 12 months, with the cost increasing after the following year. Whereas Netflix charges a monthly subscription fee of Rp. 109,000.00, there are even lower packages available for Rp. 69,000.00 for the mobile-only package. However, regardless of the level of ease of use, usability, or price perception of the service, the idea of adopting a new service can be frightening at times. According to Leichta et al. (2018), consumer innovativeness drove the large percentage of Netflix adoption, indicating that consumers' willingness to obtain new products or services is inextricably linked to their views. Fakhruddin (2017) also noted that this situation refers to certain people who are open to new ideas and new things concerning certain products or services. This study aims to add a few variables to the existing TAM variables from earlier research, including Service Innovation, which had been added to analyze whether service innovation plays an essential part in contributing to service adoption, similar to Consumer Innovativeness, which was added to see the innovation from the consumer's perspective, and also perceived cost to scalability.

\section{LITERATURE REVIEW}

\section{Theory of Acceptance Model}

The relationship between TAM and perceived ease of use is intended to demonstrate that the level of ease with which a technology can be used has a significant impact on the acceptance or rejection of technological development. For example, when it comes to adopting new streaming services such as Netflix, the ease with which the service can be used and understood will have an impact on whether the user feels compelled to adopt or reject the service. According to Belanche et al. (2014), TAM is strongly linked to the cost-benefit paradigm, in which decision-making is based on the individual's subjective perceptions of performance and effort.

Improvements in output, productivity, efficiency, overall utility, time savings, and improved work performance are examples of perceived usefulness metrics. As a result, the metrics for perceived ease of use include ease of learning, ease of communication, ease of comprehension, ease of use, consistency, and usability. People who have an inherent purpose will perceive new technology as less difficult to use than others

ECRTD-UK https://www.eajournals.org/

ULR: https://doi.org/10.37745/ijbmr.2013 
because they enjoy using it. Intrinsically motivated people will also use technology for longer periods of time, contributing to higher performance than others. As a result, innate motivation helps to explain the perceived ease of use and effectiveness of modern technologies.

\section{Service Innovation}

Service innovation, according to the Finnish research agency Tekes (2010), is defined as the implementation of a new or significantly improved definition of a service. It may be a new customer engagement platform, a marketing network, a technical term, or some combination of the three. A service improvement frequently includes replicable elements that can be found and replicated in other cases or environments in a systematic manner. The replicable item could be the end result of the service or the entire service process, or it could be a component of it. This stands to benefit both service providers and consumers while also enhancing developers' competitive advantage. Most of the time, innovation occurs in non-technological areas such as new customer interface systems, fulfillment processes, new technology applications in the service phase, new modes of supply chain activity, or new ways of organizing and handling services (Tumenbayar, et al., 2019). In Netflix's scenario, the innovation could be the availability of options via the ever-expanding programs they implemented in response to market demands, or it could be the regular maintenance to ensure the site's quality remains or even improves.

\section{Consumer Innovativeness}

Consumer innovativeness refers to the willingness of consumers to learn about new products or services, which is intrinsically tied to their opinions about such products or services. Individuals who are more innovative recognize the benefits of digital technology, believe it is less complicated, and are more likely to embrace and use new technology to achieve their personal goals. Businesses must also understand how to use new technology to improve customer service. Innovation is critical to the success of any business, but it has been proved that it is not always easy to implement innovation (Leichta et al. 2018).

\section{Perceived Ease of Use}

Perceived ease of use refers to a person's belief in the usage of computer technology in decision-making. The consumer's perception of how easy it is to use a technology explains how much they believe it will increase the fulfillment of their wants, and the experience may then be concluded to affect the consumer's behavior (Adhiputra, 2015). The user's perception that using the most modern technology or service will be nearly seamless is characterized as perceived ease of use. In the context of a streaming service, ease of use refers to the idea that consumers should put up the least amount of effort feasible in order to enjoy the service.

ECRTD-UK https://www.eajournals.org/

ULR: https://doi.org/10.37745/ijbmr.2013 


\section{Perceived Usefulness}

Perceived usefulness relates to the consumer's presumption that using technology or a device can increase customer efficiency in the workplace and contribute to the benefits they receive. According to the description, the perceived meaning of perceived usefulness is a decision-making process belief. In addition, if a person believes the information system is important, they can use it. However, if a person believes the information system is unimportant, they will not use it (Susilo, 2019).

\section{Perceived Cost}

According to Rahman and Sloan (2017), price is the most important factor that influences a purchaser's decision; prices play a part in determining customer purchases; thus, before setting a price, the business should consider certain market comparisons for a product that has a high sales volume. Pantano and Pierto (2012) conducted research on the relationship between price perception and the likelihood of product adoption, and both constructs were found to be closely related to consumer attitudes toward the use of new technology. Finally, price comparison flows and effective supply management undermine customer demand perceptions in the online environment. When adopting new technologies, consumers' cost expectations are always influenced by how they perceive lower prices (Cho, 2015).

\section{Consumer Adoption}

Consumer uptake is frequently linked to consumer adoption. Consumer adoption, on the other hand, happens to individuals on a personal level, whereas market diffusion happens in culture through creativity. It can take a long time to disseminate an invention. A theoretical cycle occurs within the subject self when the target follows the instructor's instructions (new innovation). The overall time span varies, and the method is broken down into stages. When a new concept is discovered but not implemented, it enters the adoption cycle (adopted). One of the factors driving deployment growth is the invention's very essence. Innovations must be highly adaptable (adaptive power) to the biophysical, social, economic, and consumer behavior conditions in order to be introduced (Day, et al. 2019).

\section{Research Framework}

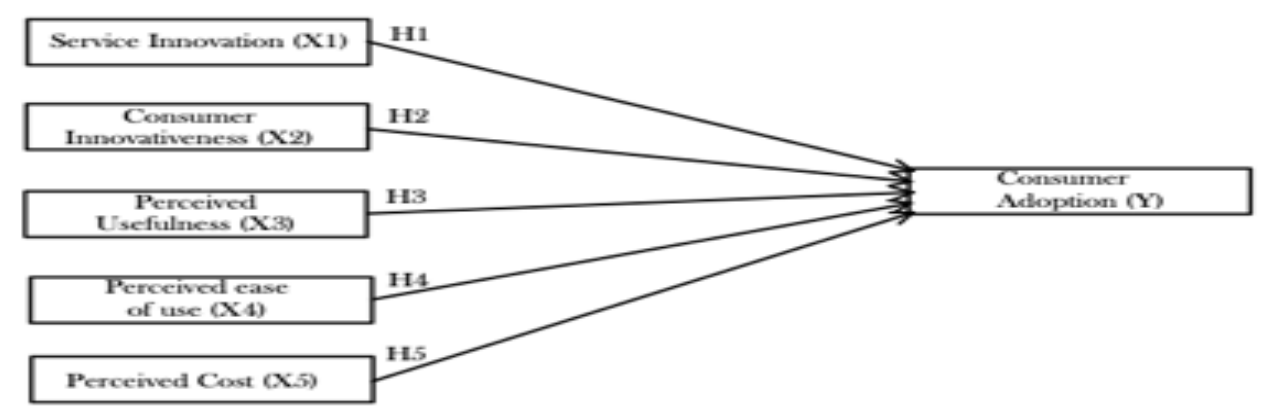

Figure 1. Research Framework

ECRTD-UK https://www.eajournals.org/

ULR: https://doi.org/10.37745/ijbmr.2013 
Print ISSN: 2052-6393(Print), Online ISSN: 2052-6407(Online)

As seen in the figure above this study takes independent variables consisting of service innovation, consumer innovativeness, perceived usefulness, perceived ease of use, and perceived cost, with the dependent variable of consumer adoption.

\section{METHODOLOGY}

The research is a quantitative analysis with a descriptive-causal approach, in which the phenomena are explained by collecting numerical data and analyzing it with mathematically based methods, specifically statistics (Alliaga\& Gunderson, 2002). Due to the controversial movie rating differences in Indonesia and internationally, the study sample consists of Netflix users in Indonesia who are 18 years or older. Purposive sampling is used to select respondents, in which the researcher selects respondents based on the characteristics of the specified subject, which in this case is the primary user of Netflix in Indonesia. The data was collected using an online questionnaire that was specifically designed with the intention of making it easy for respondents to provide responses and perspectives, as well as the minimal review time that involves a quick but thorough overview of this analysis. Prior to the questionnaire's release, several users were chosen to preview the questions in order to validate the instruments and avoid misunderstandings in the wording. The questionnaire responses are displayed on a Likert scale, with 1 indicating a strong disagreement or "strongly disagree" and 5 indicating a strong agreement or "strongly agree," while the remaining survey items are ordinal. The study requires 265 Netflix users as a sample, with a 95\% confidence interval and a 5\% margin of error. The data is analyzed using the SPSS Statistical tool, which can easily run the Pearson's correlation or Spearman's Rank Correlation tests to analyze the bivariate association between two selected variables about the correlation study's goals. It could also be used to perform the MLR analysis with the organized output of the regression analysis (Ong \&Putch, 2017).

\section{FINDINGS AND DISCUSSION}

\section{Coefficient of Correlations}

Table 1. Coefficient of Correlations - Model Summary.

Model Summary

\begin{tabular}{|c|c|c|c|c|}
\hline & $\mathrm{R}$ & R Square & Adjusted & Std. Error of \\
\hline $\mathbf{1}$ & .720 & .519 & .512 & 1.175 \\
\hline
\end{tabular}

The coefficient of determination (Adjusted R2) is used to measure how far the independent variable affects the dependent variable, as shown in the table above. The coefficient of determination obtained is 0.512 , indicating that 51,2 percent of Consumer Adoption is influenced by Service Innovation, Consumer Innovativeness, Perceived

ECRTD-UK https://www.eajournals.org/

ULR: https://doi.org/10.37745/ijbmr.2013 
Print ISSN: 2052-6393(Print),

Online ISSN: 2052-6407(Online)

Ease of Use, Perceived Usefulness, and Perceived Cost, while the remaining 48,8 percent is influenced by other unknown variables unrelated to this study.

\section{Multiple Linear Regression}

Table 2. $\quad$ Multiple Linear Regression - Coefficients.

Coefficients

\begin{tabular}{l|r|r|r|c|c}
\hline \multirow{2}{*}{ Model } & \multicolumn{2}{|c|}{ Unstandardized } & Standardized & & \multirow{2}{*}{ Sig, } \\
\cline { 2 - 5 } & \multicolumn{1}{c|}{ B. } & Std. Error & Beta & & \\
\hline Constant $)$ & 1.877 & .575 & & 3.264 & .001 \\
\hline Service Innovation & .195 & .052 & .198 & 3.745 & .000 \\
\hline Consumer Innovativeness & .075 & .033 & .105 & 2.236 & .026 \\
\hline Perceived Ease of Use & .162 & .048 & .178 & 3.382 & .001 \\
\hline Perceived Usefulness & .208 & .048 & .178 & 3.382 & .001 \\
\hline Perceived Cost & .222 & .044 & .223 & 4.999 & .000 \\
\end{tabular}

The constant indicates that if the variable of service innovation, consumer innovativeness, perceived ease of use, perceived Usefulness, perceived cost is zero, then the total of consumer adoption is 1,877 . A positive sign on the value of a (constant) indicates that consumer adoption is proven to be relevant as a dependent variable. Each variable show a significant value less than 0.50 which indicates that there is a significant impact on each of the variable on consumer adoption. According to the table result, service innovation contributed $19,5 \%$ positively to consumer adoption, proving that there is a direct positive effect by service innovation as an independent variable on consumer adoption, similarly to that, consumer innovativeness contributed $7,5 \%$ to consumer adoption, perceived ease of use also contributed $16,2 \%$ to consumer adoption, along with perceived usefulness which contributed $20,8 \%$ to consumer adoption and perceived cost contributed $22,2 \%$ to consumer adoption.

ECRTD-UK https://www.eajournals.org/

ULR: https://doi.org/10.37745/ijbmr.2013 


\section{The $t$ test}

The $\boldsymbol{t}$ test is used to examine the hypotheses conducted in this research and to determine the significance level of impact from the independent variable to dependent variable. The significance of $\boldsymbol{t}$ test can be measured by comparing the t-count in the table with the t-table value at $\mathrm{df}(\mathrm{n}-\mathrm{k}-1)=360$ and $\mathrm{a}=5 \%$ which is equal to 1.96657 . Based on the table above, each variable shows a t-count value higher than the t-table with significance level lower than 0.05 this indicates that service innovation, consumer innovativeness, perceived ease of use, perceived usefulness and perceived cost have a significant and positive impact on consumer adoption of Netflix in Indonesia.

\section{CONCLUSIONS}

According to the findings, the adoption of Netflix was aimed at people who are always looking for constant improvement and changes for the sake of convenience. Consumers are always drawn to a service that offers continuous improvements by adding new products or features for the better; they are drawn to newer features that allow them to use the service with such ease and convenience (Hong, et al., 2016). The concept of a useful yet easy to use service is advantageous to the company because consumers prefer services that require minimal effort to use and understand. This aspect also allows Netflix to be adopted by users from various backgrounds because it does not limit adoption to users with advanced knowledge of technology but also users with limited knowledge of technology use. Pricing comparison is also important in determining whether a service is worth adopting; the findings show that consumers prefer lower prices but would like to receive a high-quality or medium-quality service in return; this indicates that consumers would most likely prefer a service that is most convenient for their pockets without having to deal with the disadvantages of using it.

\section{References}

Abdullah, D. \& Krishnaswamy, J. \&Norhayati, S. \&Bahari, K. \& Md Nor, N. (2016). The Effects of Perceived Interactivity, Perceived Ease of Use, and Perceived Usefulness on Online Hotel Booking Intention: A Conceptual Framework. International Academic Research Journal of Social Science. 2. 1-5.

Adhiputra, M. W. (2015). Aplikasi Technology Acceptance Model TerhadapPenggunaLayanan Internet Banking. Calbi Socio JurnalBisnis dan Komunikasi, 2 (1), 55-56.

Ajzen, I. And Fishbein, M. (1980). Understanding Attitudes and Predicting Social Behavior. Englewood Cliffs, New Jersey: Prentice-Hall.

Alalwan, A.A., Dwivedi, Y.K., Rana, N.P.P. and Williams, M.D. (2016), "Consumer adoption of mobile banking in Jordan: Examining the role of usefulness, ease of use, perceived risk and self-efficacy", Journal of Enterprise Information Management, Vol. 29 No. 1, pp. 118-139. https://doi.org/10.1108/JEIM-04$\underline{2015-0035}$

Aliaga, M. and Gunderson, B. (2002) Interactive Statistics. Thousand Oaks: Sage Publications.

ECRTD-UK https://www.eajournals.org/

ULR: https://doi.org/10.37745/ijbmr.2013 
Print ISSN: 2052-6393(Print),

Online ISSN: 2052-6407(Online)

Ancok, Djamaludin. (1989). Tehnik Skala PenyusunanPengukur. Pusat penelitiankependudukanUGM Yogyakarta

Arikunto, S. 2010. ProsedurPenelitianSuatuPendekatanPraktik. Jakarta: RinekaCipta.

Bate, A. (2018). Resistensi Telkom Terhadap Netflix dalamIndustriOn Demand Streaming Service di Indonesia (PendekatanEkonomiPolitikKomunikasi).

Belanche, D., Casaló, L. V., \&Flavián, C. (2012). Integrating trust and personal values into the Technology Acceptance Model: The case of e-government services adoption. Cuadernos De Economía Y Dirección De La Empresa, 15(4), 192-204. doi:10.1016/j.cede.2012.04.004

Cebeci, U., Ince, O., \& Turkcan, H. (2019). Understanding The Intention To Use Netflix: An Extended Technology Acceptance Model Approach. International Review of Management and Marketing, 9(6), 152-157. DOI:10.32479/irmm.8771

Chauhan, Vikas \& Yadav, Rambalak\& Choudhary, Vipin. (2019). Analyzing the impact of consumer innovativeness and perceived risk in internet banking adoption: A study of Indian consumers. International Journal of Bank Marketing. 37. 323-339. 10.1108/IJBM-02-2018-0028.

Chiu, C., \& Yang, C. (2019). Competitive advantage and simultaneous mutual influences between information technology adoption and service innovation: Moderating effects of environmental factors. Structural Change and Economic Dynamics,49, 192-205. DOI:10.1016/j.strueco.2018.09.005

Cho, Y. (2015). Exploring Factors That Affect Usefulness, Ease Of Use, Trust, And Purchase Intention In The Online Environment. International Journal of Management \& Information Systems, 19(1), 21-36.

Creswell, J. W. (2012). Educational research: Planning, conducting, and evaluating quantitative and qualitative research (4th ed.). Boston, MA: Pearson.

Day, S., Godsell, J., Masi, D., \& Zhang, W. (2020). Predicting consumer adoption of branded subscription services: A prospect theory perspective. Business Strategy and the Environment,29(3), 1310-1330. DOI:10.1002/bse.2435

Mirjam, D. (2015). Rogers's Theory on Diffusion of Innovation-The Most Appropriate Theoretical Model in the Study of Factors Influencing the Integration of Sustainability in Tourism Businesses. Procedia - Social and Behavioral Sciences. 195. 1453-1462. 10.1016/j.sbspro.2015.06.443.

Denaputri, A., \& Usman, O. (2019). Effect of Perceived Trust, Perceived Security, Perceived Usefulness, and Perceived Ease of use on Customers' Intention to Use Mobile Payment. SSRN Electronic Journal. DOI:10.2139/ssrn.3511632

DU, H., Whinston, A.B., Lu, T., and Liu, J. (2010). An empirical study of consumer adoption of mobile data services (MDS) in China. Second International Conference on MultiMedia and Information Technology, 298-301.

Durst, S., Mention, A., and Poutanen, P. (2015). Service innovation and its impact: What do we know about? InvestigacionesEuropeas De Dirección Y Economía De La Empresa,21(2), 65-72. doi:10.1016/j.iedee.2014.07.003

Ernungtyas, N. F. (2017). Perceived Usefulness and Ease of Use on Mobile Communication App Reviews. Proceedings of the International Post-Graduate Conference on Media and Communication. DOI:10.5220/0007327002180224

ECRTD-UK https://www.eajournals.org/

ULR: https://doi.org/10.37745/ijbmr.2013 
Fakhruddin, A. (2017). AnalisisPengaruh Consumer Innovativeness dan Market Maven terhadap Opinion Leadership. JurnalManajemenBisnis, 8(2), 142-162.

Formisano, V., Fedele, M., \& Antonucci, E. (2016). Innovation in Financial Services: A Challenge for Start-Ups Growth. International Journal of Business and Management,11(3), 149. DOI:10.5539/ijbm.v11n3p149

Samuel, F.W. (2014). Perceived usefulness, ease of use, and risk in Social Media Adoption with the in Workspace. 20-26. 10.1145/2617848.2617852.

Giannopoulou, E., Gryszkiewicz, L., and Pierre-Jean, B. (2014). Creativity for Service Innovation: a Practice-Based Perspective. Managing Service Quality. 24. 23-44. 10.1108/MSQ-03-2013-0044.

Ghozali, Imam. (2001). AplikasiAnalisis Multivariate Dengan Program SPSS. Semarang: Badan Peneliti Universitas Diponegoro.

Herman, FassouHaba\& Hassan, Zubair \&Dastane, Omkar. (2017). Factors Leading to Consumer Perceived Value of Smartphones and its Impact on Purchase Intention. Global Business and Management Research: An International Journal. 9. 42-71.

Ho, C., \& Wu, W. (2011). Role of Innovativeness of Consumer in Relationship between Perceived Attributes of New Products and Intention to Adopt. International Journal of e-Business Management. 9. 180-194.

Hong, T. L., Cheong, C. B., \& Rizal, H. S. (2016). Service Innovation in Malaysian Banking Industry towards Sustainable Competitive Advantage through Environmentally and Socially Practices. Procedia - Social and Behavioral Sciences, 224, 52-59. DOI:10.1016/j.sbspro.2016.05.399

Hsieh, Y., \& Chou, Y. (2018). Modeling the impact of service innovation for small and medium enterprises: A system dynamics approach. Simulation Modelling Practice and Theory,82, 84-102. DOI:10.1016/j.simpat.2017.12.004

Ismail, H. A. (2016). Intention to Use Smartphone Through Perceived Compatibility, Perceived Usefulness, and Perceived Ease of Use. JurnalDinamikaManajemen, 7(1), 1. doi:10.15294/jdm.v7i1.5748

Izuagbe, R., Ifijeh, G., Izuagbe-Roland, E. I., Olawoyin, O. R., \&Ogiamien, L. O. (2019). Determinants of perceived usefulness of social media in university libraries: Subjective norm, image, and voluntariness as indicators. The Journal of Academic Librarianship,45(4), 394-405. DOI:10.1016/j.acalib.2019.03.006

Jang, Y., Chen, C. C., \& Miao, L. (2019). Last-minute hotel-booking behavior: The impact of time on decision-making. Journal of Hospitality and Tourism Management, 38, 49-57.

Jeong, Seok Chan \& Kim, Sang-Hyun \& Park, Ji \& Choi, Beomjin. (2016). DomainSpecific Innovativeness and New Product Adoption: A Case of Wearable Devices. Telematics and Informatics. 34. 10.1016/j.tele.2016.09.001.

Judd, Charles, and,McCleland, Gary (1989). Data Analysis. Harcourt Brace Jovanovich

Kima S. C., Yoonb, D. and Han E. K. (2020) 'Antecedents of mobile app usage among smartphone users, Journal of Marketing Communications; DOI: 10.1080/13527266.2014.951065.

Korwatanasakul, W. (2018). Factors influencing technology adoption of people with visual impairment: a case study of financial transactions through an automatic teller machine (ATM). Kasetsart Journal of Social Sciences.

ECRTD-UK https://www.eajournals.org/

ULR: https://doi.org/10.37745/ijbmr.2013 
Print ISSN: 2052-6393(Print),

Online ISSN: 2052-6407(Online)

Lavrakas, Paul. (2008). Encyclopedia of Survey Research Methods. $10.4135 / 9781412963947$.

Lawler, R. (2020, February 16). Netflix never slowed down in 2016. Retrieved May 03, 2020, from https://www.engadget.com/2016-12-23-netflix-never-sloweddown-in-2016.html

Lawler, R. (2020, March 06). Netflix changes how it counts viewing popularity pumps up 'The Witcher'. Retrieved April 2, 2020, from https://www.engadget.com/2020-01-21-netflix-viewing-stats-the-witcher.html

Leicht, T.; Chtourou, A.; Youssef, K.B. Consumer innovativeness and intentioned autonomous car adoption. J. High. Technol. Manag. Res. 2018, 29, 1-11.

Liu, C.H., \& Lee, T. (2016). Service quality and price perception of service: Influence on word-of-mouth and revisit intention. Journal of Air Transport Management. 52. 42-54. 10.1016/j.jairtraman.2015.12.007.

Lyu, J., Sadachar, A., \& Hahn, K. (2017). Does Consumer Innovativeness Matter? An Examination of Multi-Dimensional Consumer Innovativeness Motivation on Intention to Adopt 3D Printed Fashion Products. DOI:10.31274/itaa_proceedings-180814-430

Morton, C., \&Anable, J., \& Nelson, J., (2016). Exploring consumer preferences towards electric vehicles: The influence of consumer innovativeness. Research in Transportation Business \& Management. 18. 10.1016/j.rtbm.2016.01.007.

Malik, S. (2012). Customer Satisfaction, Perceived Service Quality, and Mediating Role of Perceived Value. International Journal of Marketing Studies. 4. 10.5539/ijms.v4n1p68.

Magnus R., \& Karen S., Peter S., Systems Thinkers, 10.1007/978-1-4471-7475-2_12, (119-128), (2020).

Marchand, A., \& Marx, P. (2020). Automated Product Recommendations with Preference-Based Explanations. Journal of Retailing. DOI:10.1016/j.jretai.2020.01.001

Mckenna, B., Tuunanen, T., \& Gardner, L. (2013). Consumers' adoption of information services. Information \& Management,50(5), 248-257. DOI:10.1016/j.im.2013.04.004

Murray, J., Elms, J., \& Teller, C. (2017). Examining the role of store design on consumers' cross-sectional perceptions of retail brand loyalty. Journal of Retailing and Consumer Services, 38, 147-156.

Octaviani, N. (2016). Pengaruh Citra Merek Dan Persepsi Harga terhadap Keputusan Pembelian Gadget Di Toko SuryaphoneSamarinda. eJournalPsikologi. Vol. 4.No.4, Hal : 397-407.

Nanggong, A., \&Rahmatia, R. (2019). Perceived Benefit, Environmental Concern, and Sustainable Customer Behavior on Technology Adoption. 12. 31-47. 10.12695/ajtm.2019.12.1.3.

Nikou, S. (2019). Factors Driving the Adoption of Smart Home Technology: An Empirical Assessment. Telematics and Informatics. 45. 101283. 10.1016/j.tele.2019.101283.

Padlee, S. F., Thaw, C. Y., \&Zulkiffli, S. N. (2019). The relationship between service quality, customer satisfaction, and behavioral intentions. Tourism and Hospitality Management,25(1), 121-139. DOI:10.20867/thm.25.1.9

ECRTD-UK https://www.eajournals.org/

ULR: https://doi.org/10.37745/ijbmr.2013 
Print ISSN: 2052-6393(Print),

Online ISSN: 2052-6407(Online)

Pantano, E., \& Pietro, L., (2012). Understanding Consumer's Acceptance of Technology-Based Innovations in Retailing. Journal of Technology Management and Innovation. 7. 10.4067/S0718-27242012000400001.

Putri, R., \&Amali, Z. (2020, January 10). Netflix: Diblokir Telkom, Diburu Sri Mulyani, DirangkulNadiem. Retrieved May 02, 2020, from https://tirto.id/netflix-diblokir-telkom-diburu-sri-mulyani-dirangkul-nadiemerBJ

Qashou, A., \& Saleh, Y. (2018). E-marketing implementation in small and mediumsized restaurants in Palestine. Arab Economic and Business Journal,13(2), 93110. DOI:10.1016/j.aebj.2018.07.001

Qin, L. \& Li, N. \&Shenghua, Z \& Wu, S. (2016). Research on Factors Influencing Perceived Usefulness of a Virtual Teacher Community: A Case Study of Rural Teachers in Inner Mongolia, China. Telematics and Informatics. 34. 10.1016/j.tele.2016.09.008.

RahadiRiantoDedi, Zainal. 2015. Analisis Technology Acceptance model pada IndustriPerbankan. JurnalSistemInformasi, Vol.7. No.2:837-851.

Rahman, M. M., \& Sloan, T. (2017). User adoption of mobile commerce in Bangladesh: Integrating perceived risk, perceived cost, and personal awareness with TAM. The International Technology Management Review,6(3), 103. DOI:10.2991/itmr.2017.6.3.4

Saghafi, F., Moghaddam, E. N., \&Aslani, A. (2017). Examining effective factors in initial acceptance of high-tech localized technologies: Xamin, Iranian localized operating system. Technological Forecasting and Social Change, 122, 275-288.

Sambaiah, A. and Reddy, P. (2019); Determinant Factors of Digital Wallet in India: An Empirical Analysis; International Journal of Scientific and Research Publications (IJSRP) 9(9) (ISSN: DOI:http://dx.doi.org/10.29322/IJSRP.9.09.2019.p9375

Sugiyono. 2012. MetodePenelitianKuantitatifKualitatif dan R\&D. Bandung: Alfabeta. Susilo, A. Z., Prabowo, M. I., Taman, A., Pustikaningsih, A., \&Samlawi, A. (2019). A Comparative Study of Factors Affecting User Acceptance of GOPAY and OVO As a Feature of Fintech Application. Procedia Computer Science,161, 876-884. doi:10.1016/j.procs.2019.11.195

Sugiyono. (2014). MetodePenelitianKuantitatifKualitatif dan $R \& D$, cetakan ke-20. Alfabeta. Bandung

Suhir, M., Suryadi, I., \&Riyadi. (2014). PengaruhPersepsiRisiko, Kemudahan dan Manfaatterhadap Keputusan Pembeliansecara Online. JurnalAdministrasiBisnis, 8(1).

Taufik, N., \&Hanafiah, M.H. (2019). Airport passengers' adoption behavior towards self-check-in Kiosk Services: the roles of perceived ease of use, perceived usefulness, and need for human interaction. Heliyon, 5.

Tekes. (n.d.). Serve - Innovative Services Technology Programme 2006-2010. Retrieved May 19, 2020, from https://web.archive.org/web/20071012184426/http://akseli.tekes.fi/opencms/ opencms/OhjelmaPortaali/ohjelmat/Serve/en/etusivu.html

ECRTD-UK https://www.eajournals.org/

ULR: https://doi.org/10.37745/ijbmr.2013 
Print ISSN: 2052-6393(Print),

Online ISSN: 2052-6407(Online)

Terblanche, Nic \&Taljaard, Aimee. (2018). The perceived value and perceived benefits experienced by customers using travel agents. South African Journal of Business Management. 49. 10.4102/sajbm.v49i1.7.

Tumenbayar, D., Amarzaya, A., \&Navchaa, T. (2019). Structural Relationships Among In-Service Teacher's Behavioral Intention, Perceived Usefulness, Perceived Ease of Use, and Online Professional Development System Quality. 2019 Twelfth International Conference on Ubi-Media Computing (Ubi-Media). DOI:10.1109/ubi-media.2019.00068

Truong, Y. (2013). A cross country study of consumer innovativeness and technological service innovation. Journal of Retailing and Consumer Services, Vol. 20, No. 1, pp. 130-137.

Umi Narimawati. 2008. MetodologiPenelitianKualitatif dan Kuantitatif, TeoridanAplikasi. Bandung: Agung Media

Venkatesh, V., Morris, M., Davis, G., \& Davis, F. (2003). User Acceptance of Information Technology: Toward a Unified View. MIS Quarterly,27(3), 425. DOI: $10.2307 / 30036540$

Wijaya, B. S. (2012). The Development of Hierarchy of Effects Model in Advertising. International Research Journal of Business Studies,5(1), 73-85. DOI:10.21632/irjbs.5.1.73-85

Xia, B. S., \& Gong, P. (2015). Review of business intelligence through data analysis. Benchmarking, 21(2), 300-311.

Yang, F., Huang, M., Liang, C., \& Huang, C. (2017). A Study Of The Relationships Among Perceived Service Innovation, Flow Experience, And Repurchase Intention. The International Journal of Organization Innovation, 10(2), 13-28.

Zhang, Fangyu\& Sun, Siwei\& Liu, Chenlin\& Chang, Victor. (2020). Consumer innovativeness, product innovation, and smart toys. Electronic Commerce Research and Applications. 100974. 10.1016/j.elerap.2020.100974.

ECRTD-UK https://www.eajournals.org/ 